\title{
Protecting Human Rights in Austerity Claims in the UK
}

\author{
Veronika Fikfak ${ }^{1}$
}

Published online: 4 October 2016

(C) The Author(s) 2016. This article is published with open access at Springerlink.com

\begin{abstract}
In many ways, writing about the economic crisis in the UK is telling a story about the past. Recently, media and scholars have been reporting that a successful economic recovery is upon us, that the double dip recession is over and that a slow but steady expansion of the UK economy is already taking place. To put it simply, the UK appears to be out of the economic crisis. Yet, although the economy has improved, the politics of the current conservative government is still very much focused on limiting social benefits and entitlements, a move that could have been explained during the economic crisis, but one that is now questionable. In this regard, although this article appears to be about the past, it is in fact about the present-it is about the effects of the economic crisis, about the government's treatment of our most vulnerable people both during and out of a recession, and about our conception of the rule of law. The article how the adoption of a rights based approach has already changed the treatment of austerity claims in the UK. Recent constitutional developments in the UK (including the discussions about the repeal of the Human Rights Act and the adoption of a new Bill of Rights) and the danger of withdrawing from the European Convention of Human Rights make the focus on this jurisdiction especially interesting. The obvious question that arises is whether a human rights based approach is dependent on the UK being a member of the Convention. The article investigates the impact of the Human Rights Act on the current English constitutional climate and reveals the expanded potential for rights protection.
\end{abstract}

Veronika Fikfak

vf243@cam.ac.uk

1 University of Cambridge, Cambridge, UK 


\section{Introduction}

In many ways, writing about the economic crisis in the UK is telling a story about the past. Recently, media and scholars have been reporting that a successful economic recovery is upon us, that the double dip recession is over and that a slow but steady expansion of the UK economy is already taking place. To put it simply, the UK appears to be out of the economic crisis. Yet, although the economy has improved, the politics of the current conservative government is still very much focused on limiting social benefits and entitlements, a move that could have been explained during the economic crisis, but one that is now questionable. In this regard, although this article appears to be about the past, it is in fact about the present-it is about the effects of the economic crisis, about the government's treatment of our most vulnerable people both during and out of a recession, and about our conception of the rule of law.

In his article 'The European Court of Human Rights, Rule of Law and SocioEconomic Rights in Times of Crisis' in this issue, Jernej Letnar Cernic's sets out a theoretical relationship between the rule of law and the economic crisis from the perspective of the socio-economic rights obligations under the European Convention on Human Rights (the Convention). He argues for a rights-based approach to issues raised by the economic crisis, one that enables the 'minimum core of human rights' to be untouched regardless of the economic situation or temporary emergency we find ourselves in. His argument promises a better, more dignitarian protection of individuals regardless of their circumstances. It promises an enhanced recognition of human values and indirectly, the protection of the rule of law.

In this article, I build on Cernic's article and investigate how the adoption of a rights based approach has already changed the treatment of austerity claims in the domestic legal system. Since the European Convention of Human Rights operates only if implemented and applied domestically, the European Court is primarily intended to act as a last step, as a check on domestic authorities which are the primary organs for compliance with the Convention and for ensuring the protection of individuals' rights. It is only after all other-domestic-options had been exhausted that the international institution steps in and does so only if the state has gone too far in the exercise of its margin of appreciation and infringed on the "core of the right' in question. In some ways therefore, the international story told by Cernic has to be complimented by the domestic story and mirrored in those jurisdictions. We have to look at how the human rights based approach would operate in a domestic context and how it would change the judicial approach to austerity challenges.

This article therefore seeks to examine how the human rights argument applies in English jurisprudence. The aim is to determine what impact such a human rights based approach would have on challenges of austerity measures in English courts. Recent constitutional developments in the UK (including the discussions about the repeal of the Human Rights Act and the adoption of a new Bill of Rights) and the danger of withdrawing from the European Convention of Human Rights make the focus on this jurisdiction especially interesting. The obvious question that arises is 
whether a human rights based approach is dependent on the UK being a member of the Convention. The article investigates the impact of the Human Rights Act on the current English constitutional climate and reveals the expanded potential for rights protection.

I proceed in the following manner: I first investigate how austerity measures were traditionally treated by English judges and show how since the adoption of the HRA, the human rights approach has shifted the judicial inquiry and effectuated a change in the relationship between the Executive and the courts. Then, I look at what the future holds in light of Brexit and a potential withdrawal from the ECHR by the UK.

\section{Traditional Challenges of Executive Measures in the UK}

The global recession and the subsequent adoption of austerity measures have importantly undermined the social and economic rights of the most vulnerable in our societies. These threats have importantly curved the protection disabled, vulnerable people and minorities receive. In fact, the protection of specific groups of people has been an afterthought of many governments. But as with any protection of rights (and the rule of law), it is the judges who are the ultimate stop at which such displacement of entitlements is affirmed or redressed.

Often claims before English judges will turn on jurisdictional issues or on whether the decision-maker was reasonable.

\subsection{The Jurisdictional Question}

In $R$ (Green) v. Gloucestershire County Council and $R$ (Rowe and another) $v$. Somerset County Council, the claimants challenged the decision of local authorities in Gloucestershire and Somerset to withdraw funding from certain of its libraries, which resulted in radical reduction of the opening hours of local libraries and the withdrawal of mobile library services. The claimants argued that under the existing legislation the local authority was under a duty to provide comprehensive and efficient library services in their respective counties. ${ }^{1}$ They alleged that the authorities failed to properly exercise that duty by adopting fundamentally flawed and unlawful approach, i.e. by deciding what services would be provided only after identifying budget cuts. With this, the applicants alleged, the local authorities failed to identify with adequate particularity the needs which their services were required to address. ${ }^{2}$

Judge McKenna underlined that when a is exercising its authority, they must 'ask himself the right question and take reasonable steps to acquaint himself with the relevant information to enable him to answer it correctly'. ${ }^{3}$ It is

\footnotetext{
1 S 7, Public Libraries and Museums Act 1964.

2 [2011] EWHC 2687 (Admin).

${ }^{3}$ Lord Diplock in Secretary of State for Education v. Tameside [1977] AC 1014, 1065.
} 
not for any court of law to substitute its own opinion for his; but it is for a court of law to determine whether it has been established in reaching his decision [...] he had directed himself properly in law and has in consequence taken into consideration the matters which upon the true construction of the Act he ought to have considered and excluded from his consideration matters that were irrelevant to what he had to consider. ${ }^{4}$

The claimants had argued that the statute required the local authorities to 'secure [...] that facilities are available for the borrowing of books etc', 'encouraging adults and children to make full use of those services', etc. In this regard, the two councils should have focused on the needs which their services were required to address. According to the claimants, the local authority had erred in considering (or giving priority to) the financial constraints and thus acted unlawfully.

In response, Judge McKenna held that the local authorities had not failed to comply with their statutory duties. He held that the duty under the legislation (i.e. to 'provide comprehensive and efficient library services')

could not be exempt or divorced from resource issues and could not in law escape the reductions which had been rendered inevitable in the light of the financial crisis engulfing the country. There was nothing unlawful in each of the local authorities seeking to make overall budget decisions and then considering how best to structure their respective library service provision in the light of the available funding resulting from those budget decisions assuming, of course, an adequate assessment of needs. ${ }^{5}$

He concluded '[t]his is not an example of asking the wrong question but of facing economic reality'. 6

The case is a typical example of judicial review of executive action. The claim centres on identifying how administrative power is defined by express terms of the statute which defines its scope and by the implied terms of that statute. The court focuses on the wording of the statute and on the duties of the decision-maker. Yet most often the wording of the statute is not sufficiently clear or explicit to provide a straightforward answer to the questions that arise before the court. In this case, the statute remains silent as to whether financial resources can be taken into account when deciding which needs to provide for and Judge McKenna concludes that it is within the power (and duty) of the local authorities to consider the financial constraints before deciding which services to provide and under what conditions.

Yet silence of the statute does not mean the decision-maker is free to take any consideration into account or indeed to disregard a 'relevant consideration'. During the $1920 \mathrm{~s}$ when the UK was in post-war depression, a council insisted that it could maintain its employees' wages in spite of the falling cost of living and reduced trade union scale wage rates. Under the legislation the Council had the power to pay

\footnotetext{
4 Ibid.

5 Paras. 24, 29, 30, as summarized in [2012] PTSR Digest.

6 Para. 30.
} 
employees 'such [...] wages as [...] [the Council] may think fit'. ${ }^{7}$ The scope of the power of the Council therefore appeared-at least on the face of the statuteunlimited. The Council—considering itself as 'a model employer', insisted on setting a minimum wage for adult labour at a high level regardless of the type of labour involved. Yet, as Lord Atkinson, a Law Lord put it.

The council would, in my view, fail in their duty if, in administering funds which did not belong to their members along, they put aside all [the] aides to the ascertainment of what was just and reasonable remuneration to give for the services rendered to them, and allowed themselves to be guided in preference by some eccentric principles of social philanthropy, or by feminist ambition to secure the equality of the sexes in the matter of wages in the world of labour. ${ }^{8}$

In this regard Atkinson argued, the words 'think fit' in the statute have to be construed to mean 'as the employer shall think fitting and proper' for the services rendered. 'It cannot, in my view, mean that the employer, especially an employer dealing with moneys not entirely his own may pay to his employees wages of any amount he pleases.' The wages had to be 'reasonable'. They had to 'depend, of course, on the circumstances which then exist in the labour market'.

Lord Sumner joined this interpretation. He insisted that the local authority's discretion was not absolute. As a local authority, the council was 'accountable' and therefore had to act within the confines of the law. As he concluded, 'I think it is plain that the respondents have deliberately decided not to be guided by ordinary economic (and economical) considerations.' In doing so, they acted 'beyond their powers'.?

It is clear from these holdings that by failing to take into account relevant considerations such as the lack of financial situation and limited resources and by taking into account irrelevant considerations such as 'eccentric principles of social philanthropy' and 'a feminist ambition to secure the quality of sexes', the council had made an unlawful decision. ${ }^{10}$ As constitutional scholars comment: 'the doctrine of relevancy allows potentially extensive judicial intervention in the administrative process, permitting the policy preferences of the decision-maker to be swept away if the matters upon which they are founded can be characterised by the court as irrelevant'. ${ }^{11}$ It is the judges, therefore, who decide what is lawful and what is unlawful. Whilst they will 'often accept the decisions of the local authority simply because they are themselves ill equipped to weigh the merits of one solution of a practical question as against another', ${ }^{12}$ in certain circumstances they may refuse to show such great reluctance and 'attempt to determine how, in their opinion, the discretion ought to be exercised' 13

\footnotetext{
7 Council Management Act 1855.

8 Roberts v. Hopwood [1925] AC 578.

9 Lord Sumner.

10 Today's approach to gender equality is considerably different and no longer considered an irrelevant consideration. Next section reveals how considerations of equality have impacted austerity claims.

11 Elliott et al. (2014), p. 238.

12 Lord Sumner.

${ }^{13}$ Kruse v. Johnson [1989] 2 QB 91, 99 Lord Russell.
} 
What is clear from both cases is that the economic situation is a crucial consideration judges will take into account in the interpretation of the scope of local authorities' statutory duty. If the decision-maker takes the fact into account in the process of exercising its function, the court will welcome such interpretation as part and parcel of decision-makers statutory duty. If, on the contrary, the local authority fails or even refuses to consider the financial resources, the court will do so for it.

\subsection{Wednesbury Reasonableness}

Austerity measures are also inspected in claims that require judges to assess more closely the decisions made by the administrative body, which go beyond narrowly assessing the scope of the authority's power under statute. In some cases, courts will look at the balance struck by the local authority between individual's needs and the authority financial resources.

In $R v$. Gloucestershire County Council and another, ex parte Barry ${ }^{14}$ the House of Lords had to determine whether in the provision of services to an elderly and infirm person, the local authority could properly take into account its own financial resources when assessing the elderly man's needs under Chronically Sick and Disabled Persons Act 1970 (CSDA). Barry had been entitled to home help, pension, cleaning and laundry and meals on wheels. However, because of funding cuts, the local authority would have to withdraw the cleaning and laundry services.

Before the court, the argument was made that a person's needs depend upon the nature and extent of his disability. 'They cannot be affected by, or depend upon, the local authority's ability to meet them. They cannot vary according to whether the authority has more or less money currently available [...] since the person's needs have not changed.' ${ }^{15}$ Lord Nicholls disagreed: The argument 'is flawed by a failure to recognise that needs for services cannot sensibly be assessed without having some regard to the cost of providing them. A person's need for a particular type or level of service cannot be decided in a vacuum from which all considerations of cost have been expelled.' He insisted that the social worker in determining what a person needs has to judge the needs for assistance against some standard, for example, an acceptable standard of living today. It is the local authority that sets the standards to be applied within its area.

The local authority's assessment takes place in multiple stages: first, the authority has to take into account current standards of living, with all the latitude inherent in this concept. Then the authority must consider the nature and extent of the disability. The authority will further take into account the manner in which, and the extent to which, quality of life would be improved by the provision of a specific service, for example, by home care, once a week or more frequently. The authority should also have regard to the cost of providing that specific service. Ultimately, the relative cost will be balanced against the relative benefit and the relative need for that benefit. He continued:

\footnotetext{
${ }^{14}$ [1997] UKHL 58, [1997] AC 584.

15 Ibid., 604.
} 
Once it is accepted, as surely must be right, that cost is a relevant factor in assessing a person's needs for the services listed in section 2(1), then in deciding how much weight is to be attached to cost some evaluation or assumption has to be made about the impact which the cost will have upon the authority. Cost is of more or less significance depending upon whether the authority currently has more or less money. Thus, depending upon the authority's financial position, so the eligibility criteria, setting out the degree of disability which must exist before help will be provided with laundry or cleaning or whatever, may properly be more or less stringent. ${ }^{16}$

When Lord Nicholls was challenged in proceedings that allowing the local authority to consider costs in any way it chose would mean collapsing the duty under the statute into a power, he disagreed. A local authority must carry out its functions under the statute 'in a responsible fashion', he said. In the event that the local authority acted unreasonable, a disabled person would have a remedy.

It is important to underline that the question raised in Barry was different from those that had arisen as jurisdictional issues. Here, the case did not revolve directly around the scope of the power of local authority. The Court was not asked to determine whether financial resources could be taken into account in the interpretation of the local authority's own power, instead what was at stake was whether in assessing the needs of the individual, the council could take the financial constraints into account. In this second option, the finances would therefore affect the interpretation of what the individual needed. The focus was again on the decision-maker and how far it could use financial resources to restraint its provision of services.

In this context, the individual's needs were not defined or regarded as rights. Instead, the use of the term 'benefit' is consistent. This move is crucial because the act of labelling the need as requiring a benefit rather than entitling the individual to have his rights met implies that social rights (housing, disability benefits etc.) are not rights, which the government and administrative bodies have to always respect or meet in their work. These are not civil and political rights protected by the Convention, whereby in the exercise of governmental function the state would be expected to uphold them. Instead of speaking of rights-language that in the UK implies a certain element of inalienability, the language used refers to benefits, allowing discretionary (and also discriminatory) behaviour from administrative decision-making bodies.

The terminology is important for another reason-because it triggers a more relaxed standard of protection. Nicholls insists the intervention can come only if the local authority acted unreasonably or irrationally. In English administrative law, this traditional standard of review requires that judges adopt an increased scope of deference towards executive decision-making, allowing it to redirect resources to other areas. Instead of adopting a more interventionist approach reserved for rights, one that would have required the executive to seek the least restrictive means,

16 Ibid., 605. Emphasis added. 
judges have had to apply the non-rights jurisprudence, a move that ends up upholding most of executive's decisions.

When an administrative decision is taken-whether it curbs housing or disability benefits or limits the provision of services whilst indirectly targeting different communities, the test domestic courts apply is the Wednesbury test. The test is concerned with more than the manner in which decisions are made, but rather with the content of the decisions themselves. In that regard, the judge's role in assessing the administrative, executive decision is not to intervene to overturn the decision simply because the court disagrees with it. To have the right to intervene, the court would have to conclude that the decision was so unreasonable that no reasonable authority would ever consider imposing it. As Lord Greene, M. R. said

It is true the discretion must be exercised reasonably. Now what does that mean? Lawyers familiar with the phraseology commonly used in relation to exercise of statutory discretions often use the word 'unreasonable' in a rather comprehensive sense. It has frequently been used and is frequently used as a general description of the things that must not be done. For instance, a person entrusted with a discretion must, so to speak, direct himself properly in law. He must call his own attention to the matters which he is bound to consider. He must exclude from his consideration matters which are irrelevant to what he has to consider. If he does not obey those rules, he may truly be said, and often is said, to be acting 'unreasonably.' Similarly, there may be something so absurd that no sensible person could ever dream that it lay within the powers of the authority. Warrington LJ [...] gave the example of the redhaired teacher, dismissed because she had red hair. ${ }^{17}$ That is unreasonable in one sense. In another sense it is taking into consideration extraneous matters. It is so unreasonable that it might almost be described as being done in bad faith; and, in fact, all these things run into one another. ${ }^{18}$

Wednesbury test is the traditional test applied in judicial review. It is not a correctness test - the court does not enquire whether the executive reached a correct decision. Instead, the question is whether the decision was reasonable. The application of this test has extremely important implications on how challenges of austerity measures are presented or indeed how they are perceived.

First, the focus is on the legality of the measures rather than looking at the impact austerity measures have had on individuals. In judicial review claims, the judge focuses on whether the decision taken by the government (or administrative body) was unreasonable or irrational. He asks the question: was the decision so unreasonable that no reasonable administrator would ever make it? The focus is therefore clearly on the discretion possessed by the decision-maker, not on the individual or his well-being. Especially when the issue concerns resources and their distribution amongst people, judges are unlikely to hold that the decision-maker was irrational.

\footnotetext{
17 Short v. Poole Corporation [1926] Chapters 66, 90, 91.

18 [1948] 1 KB 223, 229.
} 
As Laws has stated 'the courts, while broadly adhering to the monolithic language of Wednesbury, have to a considerable extent in recent years adopted variable standards of review' to suit the subject matter of the case before them' ${ }^{19}$ In the context of social rights this has led to deference, which in practice involves judges simply refusing to determine whether impugned administrative action is unlawful because, for some reason, they think it would be inappropriate for them to do so'. ${ }^{20}$ The problem with deference is how it is conceived: is it 'an area of [administrative] judgment within which the judiciary will defer, on democratic grounds, to the considered opinion' ${ }^{21}$ of an elected decision-maker or is it an exercise in 'attaching an appropriate amount of weight to the views of the decisionmaker' $?^{22}$ The difference between the two views is one of degree-the first view removes the issues of social rights completely from any consideration by judges, whilst the second places some (though not complete) weight on the judgment of the administrative decision-maker. At its greatest, deference treats social rights (benefits) as non-justiciable and non-enforceable in courts. They fall within the 'forbidden area' into which courts will not enter. ${ }^{23}$ There is no assessing the appropriateness of the measure or whether it is proportionate to achieve the aim pursued. There is no consideration of other less restrictive means. In short-because of the nature of the claim involved, the judge is completely removed from inquiry.

Deference-whether such which removes a whole area from judicial consideration or such which allows some judicial involvement-is always self-imposed. It is in effect restraint exercised by judges when they assess their involvement not to be opportune. It is most often present in claims challenging austerity measures. Often judges believe they should not be seized at all to adjudicate these claims because they concern issues of policy, issues on which courts are ill-equipped to adjudicate. The point is one of relative institutional competence. The decision-maker arguably possesses a degree of expertise and experience that is unavailable to the court. When this is the case, judges find it appropriate to defer and attach greater weight to the opinion of the decision-maker. In austerity challenges, often this deference turns into non-justiciability. As Laws LJ put it:

Greater or lesser deference will be due according to whether the subject matter lies more readily within the actual or potential expertise of the democratic powers or the courts. Thus, quite aside from defence, government decisions in the area of macro-economic policy will be relatively remote from judicial control. $^{24}$

Ultimately therefore the judicial approach to austerity claims which focuses on reasonableness of the decision-maker and perceives interests as benefits rather than

\footnotetext{
${ }^{19}$ Laws (1998), pp. 186-187.

${ }^{20}$ Elliott et al., n. 11, p. 267, referring to Allan's critique in [2006] CLJ 671, 687.

21 Lord Hope in $R$ v. Director of Public Prosecutions, ex p Kebilene [2000] 2 AC 326, 380.

22 Elliott et al., n. 11, p. 268.

23 GCHQ, Diplock case.

24 International Transport Roth GmbH v. Secretary of State for the Home Department [2002] EWCA Civ $158,[87]$.
} 
rights leads to little protection of individuals during times of crisis. Judges refuse to intervene and as a consequence the decision-maker enjoys an expanded area of unsupervised discretion.

\section{The Impact of Human Rights Language on Austerity Challenges}

In the previous section, we saw that judges in challenges of austerity measures focus on the actions of the decision-maker, that they assess this for their compliance with the powers contained in statutes as well as investigate whether the decision taken was reasonable. The focus, therefore, is on the decision-maker. In this section, I show how the human rights language has changed the treatment of challenges of executive actions. Judicial review claims that are made in human rights language are often treated differently because - as will become clear from the analysis belowthey shift the focus of judicial inquiry not on the decision-maker but on the individual affected by the measure.

\subsection{Focus on Rights}

Multiple human rights statutes have been passed in the UK in response to the development of EU law and the jurisprudence of the ECtHR. These laws seek to keep pace with the expansion of protections provided to the individuals by these supra national bodies and to fulfil the international obligations imposed on the UK. The duties imposed by these statutes require of decision-makers to adopt a specific attitude in the process of administrative decision-making. In particular, decisionmakers are expected to take into account the needs of specific groups and the likely impact administrative decisions will have on these groups. For example, in the context of equality provisions, public authorities are required in the exercise of their function to give 'due regard' to specific albeit overlapping statutory equality needs: to give due regard to age, race, sex, and disability. The duties imposed by the statute include: the duty for the public authority in carrying out its function to have due regard to the need to eliminate discrimination; to eliminate harassment, to promote equality of opportunity, to take steps to take account of disabilities, even where that involves treating disabled persons more favourably than other persons, etc. ${ }^{25}$

These equality questions were considered by judges in a number of cases. In Green, discussed earlier, in which Judge McKenna ruled that the local authority was acting within its statutory duty when it took into account budget cuts before deciding on the scope of library services it would provide, the judge found that under equality legislation, the local authorities were required to have due regard to the needs of specific groups and consider whether measures adopted will disproportionately affect these groups. The judge noted that the withdrawal of a local library might well indirectly discriminate against people with physical disabilities perhaps because they might find it more difficult to travel further than others; against women because they were more likely to be responsible for child

$\overline{25} 1975$ Sex Discrimination Act; 1995 Disability Discrimination Act; 2010 Act Equality Act. 
care and in rural areas against the elderly not only because they might find it disproportionately more difficult to travel the extra distance but also because there might be proportionately more of them living in a particular area. Such discrimination would be unlawful unless objectively justified balancing the disadvantages with the strength of the need to pursue the policy in question. The real question on this aspect of the case was whether there was a conscious directing of the mind by the decision-makers to their obligations under the legislation and, in particular, to the need to exercise the duty to have due regard in substance and with rigour and based on sufficient information, appropriately analysed. The judge concluded that on the preponderance of the evidence, no such due regard was had in substance. In order to discharge their respective duties, the local authorities should have undertaken a sufficiently thorough information gathering exercise and then properly analysed that information. ${ }^{26}$

A similar approach was adopted in Williams, where austerity measures led to a closure of libraries and introduction of partnership regime in which library services were shared between different locations within the same local authority. ${ }^{27}$ The case focused mostly on what equality impact assessments the local authority was required to undertake under the 'due regard' concept. ${ }^{28}$ As Judge Wilkie held, due regard required more 'than simply giving consideration to the issue[s]' raised by the legislation. ${ }^{29}$ 'Due regard' imposed on the local authority that it does not treat the consideration of the needs of different groups and the impact as a matter of 'ticking boxes'. Instead, the duty to give due regard had to be 'kept in mind by decision makers throughout the decision making process. It should be embedded in the process but can have no fixed content bearing in mind the range of potential factors and situations. ${ }^{30}$ What observance of that duty requires will be fact sensitive and may vary depending on the situation, time and stage. ${ }^{31}$

In this context, the task of the Court was composed of two stages: first, the Court checked whether the statutory obligation to give 'due regard' has been discharged. It enquired whether a process was followed in which the decision-maker took into consideration the information it is required to look to under legislation. After this had been ascertained, the Court then looked at the decision which flowed from this process. This involved the Court deciding whether the authority had, in fact, surmounted the threshold required by the statute, i.e. whether the due regard was kept in mind at all times, whether the authority gathered and took into account all available information, and whether it had considered the various facts and opinions arising from the consultation process.

The Court found that the Surrey County Council had erred in law having concluded that no "equality impact issue had arisen in the course of the consultations'. The issue that concerned the judge the most was that in the process

\footnotetext{
${ }^{26}$ [2011] EWHC 2687 (Admin), [122, 130, 131].

27 [2012] EWHC 867 (QB).

${ }^{28} R$ (Rahman) v. Birmingham City Council [2011] EWHC 944 (Admin).

${ }^{29} R$ (Chavda) v. LB Harrow [2007] EWHC 3064 (Admin).

${ }^{30}$ [2012] EWHC 867 (QB), [16].

${ }^{31} R$ (Bailey) v. LB Brent [2011] EWCA Civ 1586 para. 83.
} 
of deciding to close the libraries and shift resources to be shared amongst multiple authorities, the Council had failed to recognise that the complex and radical change of a magnitude proposed would require, amongst other things, training. '[E]mbedding equality issues in the culture of the Defendant involved particular emphasis being placed on significant compulsory training of all members of management and staff, by having equality issues as individual appraisal targets for staff and by having training for managers and tailored training in particular directorates. ${ }^{32}$ The equality impact assessment report explicitly warned that residents and equality adviser groups had not yet been consulted and that such consultation would be important to inform the proposals, and to develop mitigating actions against negative impacts. It was clear therefore that although the Council had paid attention to take into account factors required by the equality legislation, it did not take into account all the information. Judge Wilkie concluded: 'In my judgment, the reliance by the Defendant on the same bland assertions that training would be required and monitored, fell substantially short of enabling the cabinet members to give due regard to this obvious equality issue at the stage the process had reached. ${ }^{33}$

Although austerity measures may therefore survive judicial scrutiny, judges will be careful to assess whether the local authority had complied with the requirements of the human rights legislation. In this context, they will not only look at the process in which the decision was made but also at the quality of the consideration of human rights factors. Once the authority has surmounted the threshold of 'due regard', through these two stages, the lawfulness of the decision which emerges from the consideration of those matters and all the other relevant (possibly countervailing) factors, the Court will only interfere if the local authority has acted outside the scope of any reasonable public authority in the circumstances. ${ }^{34}$

It is clear from this analysis that human rights legislation has considerably changed both the scope of the duty of the administrative decision-maker as well as the function of the judge. Austerity measures are not automatically allowed because the decision-maker is allowed to make provisions for economic and financial situation. In fact, even in an economic crisis when pressure is intense to reduce spending, this cannot come at the cost of vulnerable groups whom the measure would disproportionately and discriminatorily affect. The power of the decisionmaker has therefore been considerably reduced, whilst its duties have expanded. The question of complying with equality requirements (often referred to as a public sector equality duty) now forms part and parcel of administrative body's function.

As far as judicial function is concerned, a gradual shift has taken place. Whilst statutory interpretation necessarily focuses the judge on the decision-maker, its power and duties, the legislation requires that he inquire into whether individual's needs have been sufficiently considered in the decision-making process. Through this assessment, judge's attention shifts from the 'power' of the decision-maker to

\footnotetext{
32 [2012] EWHC 867 (QB), [116].

33 Ibid., [127].

${ }^{34}$ R(Brown) v. SS Work and Pensions [2008] EWHC 3158 (Admin)); 21. That approach has been followed in a number of first instance decisions such as $R$ (Boyejo) v. LB Barnet [2009] EWHC 3261 (Admin), $R$ (Hajrula) v. London Councils [2011] EWHC 448 (Admin) and JM.
} 
the rights of the individual. The decision-maker is therefore no longer completely at the centre of the judicial inquiry. As we see from Wilkie's discussion of the 'due regard' standard, the deference to the administrative body will thus only kick in at the third stage - after the judge has checked that the 'due regard' duty has been discharged and after establishing that the appropriate standard of 'due regard' had been met.

As the results in both Green and Williams show, when human rights protections are incorporated into the statute, they allow the judge to consider the needs and impact on individual already at the jurisdictional stage of judicial review. They thus allow the judge to impose on the decision-maker his own interpretation of the law. Usually, they result in an enhanced protection for the individual and thus present a promising option for future austerity challenges.

\subsection{The Proportionality Analysis}

The other shift that has occurred with the adoption of the Human Rights Act and the internalisation of the ECHR jurisprudence into English law is the substitution of the Wednesbury unreasonableness test with the proportionality test. In the context of claims that give rise to human rights, executive action will be scrutinised by employing the proportionality analysis. This includes determining whether the administrative objective is sufficiently important to justify limiting a fundamental right; whether the measure designed to meet the administrative objective is rationally connected to it; and finally whether the means used to impair the right are no more than is necessary to accomplish this objective. ${ }^{35}$ This, as the analysis of the jurisprudence shows, has shifted the judicial attention to the individual and his rights.

In Child Poverty Action case, ${ }^{36}$ the claimants argued that the Secretary of State had unlawfully made subordinate legislation imposing a cap on the amount of welfare benefits which can be received by claimants in non-working households, equivalent to the net median earnings of working households. The claimants, comprising the mother and youngest child of three lone parent families whose welfare benefits were substantially reduced as a result of the cap, issued judicial review proceedings against the Secretary of State, challenging the lawfulness of the amended Regulations on the grounds, that by including child-related benefits in the list of prescribed benefits, the Secretary of State had indirectly and unjustifiably discriminated against women, contrary to Article 14 of the ECHR read with the right to the peaceful enjoyment of one's possessions in Article 1 of the First Protocol to the Convention. The claimants also alleged that the Minister had failed to treat the best interests of children as a primary consideration when making the Regulations, as required by Article 3.1 of the United Nations Convention on the Rights of the Child.

The Secretary of State recognised that Regulations resulted in differential treatment of men and women in relation to welfare benefits, because most non-

\footnotetext{
${ }^{35} R$ (Daly) v. Secretary of State for the Home Department [2001] UKHL 26.

${ }^{36}$ [2015] UKSC 16, [2015] 1 WLR 1449.
} 
working households receiving the highest levels of benefit were lone parent households and most lone parents were women, and that the benefits could amount to 'possessions' within A1P1, but the claim was resisted on the grounds that the differential treatment was justified.

The Supreme Court dismissed the claim. Yet, its approach could not be more different than the one adopted when applying the Wednesbury unreasonableness test. In determining whether the reduction of benefits was justified the Court engaged in an enhanced review of the administrative measure. The starting point for the Court was the rights protected by the Convention, including the UN Convention on the Rights of the Child. Although the Government had already acknowledged this fact, the Court reiterated that there was no doubt that the benefits fell within the scope of A1P1 and that the treatment in question although equally applied to men and women indirectly discriminated against women.

This initial focus on rights is crucial-the 'benefit' is no longer merely a 'benefit' accorded to individuals depending on the whims of the decision-maker. The benefit is defined as a 'right' protected both by the legislature through the Human Rights Act, as well as by the Strasbourg Court through the ECHR. In assessing the scope and lawfulness of the infringement, the role of the court-and the judge-therefore changes. He is no longer determining the reasonableness of the administrative body, instead he works to protect the individual's rights in accordance with the jurisprudence of the ECtHR.

First, the judge's attention is drawn to the right and individual in question and establishing the impact the measure has had or might have on the individual. Lady Hale, for example, argued, in Child Poverty Action case that

The disproportionate impact on lone parents is relatively straightforward to explain. [...] It is much more difficult for lone parents to move into paid employment, even for the $16 \mathrm{~h}$ which would take them out of the cap. It is more difficult for them to do so, the more children they have, because of the problems of delivering and collecting children from different schools or day care placements, the problems of making appropriate day care arrangements for very young children and for all children during the school holidays, the problems of responding to their children's illnesses, accidents and to casual school closures. $^{37}$

Second, because the language is focused on conferring a right, the standard of intensity with which the action of the administrator is looked at is heightened and the test of proportionality applies. It requires the judge to ensure that the measure is capable of reaching the pursued aim and that it is carefully balanced against the right it is limiting. The core of the right in question always has to be preserved. In this regard, the Court proceeds in several stages. Having established the scope of infringement into the claimant's right, the Court then continues to determine whether the curtailment of the right pursues a legitimate aim. In its inquiry, the Court is very careful to investigate the motivation of the Council in adopting the

37 Ibid., 1507, Lady Hale. 
constraining measures. It looks at witness statements and investigates evidence presented to it; it also assesses the criticisms made of each of the objectives claimed.

In this context, in Child Poverty Action, the Court was not willing to automatically accept that 'saving public money' was a legitimate aim on its own to justify discriminatory treatment in the enjoyment of Convention rights. The Court noted that the savings made were a drop in the ocean compared with the total benefit bill, let alone the total housing benefit bill. Citing the ECtHR jurisprudence, they acknowledged that although member states enjoy a broad margin of appreciation in relation to public spending and in the protection of the country's economic system, ${ }^{38}$ the objective would only be legitimate if a reasonable relationship of proportionality existed between the aim pursued and the means employed. The judiciary's focus on the individual therefore precludes an automatic exclusion of review of governmental action (as was the case in jurisdictional and Wednesbury cases in which the administrative body got to define the scope of its own power). The excuse of austerity, economic crisis, and limited financial resources cannot on its own suffice to limit social rights.

In the final stage then the Court proceeds with a balancing act: it inquires whether the legislature's policy choice in relation to general measures of economic or social strategy, including welfare benefits, are manifestly without reasonable foundation. Lord Reed looked at the different ways in which the reasonable limit to the amount of benefits which a household could receive could be calculated (e.g. average earnings of working households v. average income inclusive of benefits etc.). Yet, he resisted that the assessment of the level at which a cap would represent a fair balance between the interests of working and non-working households was a matter of political, not judicial judgment. His task was merely to determine whether the choice made by the government was reasonable. He went further: 'it is highly significant that no credible means was suggested in argument by which the legitimate aims of the Regulations might have been achieved without affecting a greater number of women than men.' In short, according to Lord Reed (majority) the government had chosen the least restrictive means to achieve the aim. Even in assessing the reasonableness of the decision, the judge therefore looks to establish a strict fit between the aim and the measure; a typical proportionality exercise. He concludes, 'Since women head most of the households at which those aims are directed, it appears that a disparity between the numbers of men and women affected was inevitable if the legitimate aims were to be achieved., ${ }^{39}$

There is a fundamental difference between assessing the 'reasonableness of the measure adopted' in the context of the proportionality test versus the reasonableness adopted as part of the Wednesbury irrationality standard. As the analysis revealed, Wednesbury test accords extensive discretion to the decision-maker. The judge does not assess the existence or acceptability of the legitimate aim, or the suitability and proportionality of the measure as against the legitimate aim. In the area of macro-

\footnotetext{
38 Andrejeva v. Latvia (2009) 51 EHRR 650; Humphreys v. Revenue and Customs Comrs [2012] 1 WLR 1545 .

39 [2015] UKSC 16, [2015] 1 WLR 1449, 1473, emphasis added.
} 
economic policy, he confers greater deference due to the Executive. The judicial function of review is therefore limited.

In contrast, in proportionality review, the scrutiny is heightened. As Lord Hope expressed in In re $G$, protection against discrimination, even in an area of social and economic policy, falls within the constitutional responsibility of the courts:

Cases about discrimination in an area of social policy, which is what this case is, will always be appropriate for judicial scrutiny. The constitutional responsibility in this area of our law resides with the courts. The more contentious the issue is, the greater the risk is that some people will be discriminated against in ways that engage their Convention rights. It is for the courts to see that this does not happen. It is with them that the ultimate safeguard against discrimination rests.

Therefore, even in the area of welfare benefits, where the court would normally defer to the considered decision of the legislature, if that decision results in unjustified discrimination, then it is the duty of the courts to say so. ${ }^{40}$

The perception of judges as to their duty appears to be different depending on the test that applies to austerity measures. Wednesbury test is defined by deference and judicial restraint, whilst human rights language and the proportionality test shifts the burden on judges. It is now their responsibility to examine the executive measure as against the individual and his protected right. They have to assess and evaluate the measures adopted and inquire whether lesser measures could have been adopted in place. Ultimately, therefore, in a proportionality situation the court steps into the shoes of the decision-maker and determines whether the balance struck is correct; ${ }^{41}$ a situation that could never have been imagined under the traditional (pre-rights) judicial review approach. As Craig argues

proportionality provides a more structured analysis of the kind which is often lacking under the Wednesbury formula [...] It requires that the courts, when striking down the decision, do so in ground which are more readily identifiable and ascertainable than is often the case under Wednesbury. [...] [this] has a beneficial effect in that it requires the administration to justify its policy choice more specifically than under the traditional Wednesbury approach. $[\ldots]$. $^{42}$

The transparency and structure accorded by the proportionality allow the court to test the administrative measure step-by-step and to inquire into its motivations as well as assessments. The hurdles that the government has to overcome in defending the austerity measure become much greater and the administration is held accountable to a higher standard. Ultimately, the objective of 'saving public money' therefore is unlikely to be enough for a measure to survive judicial scrutiny.

\footnotetext{
40 (Adoption: Unmarried Couple) [2009] AC 173, para. 48.

41 More on proportionality turning into a correctness review and concerns related to it, see Sales and Steyn (2004), p. 591.

42 Craig (1999), pp. 99-100.
} 


\section{The Promise of the Common Law for Human Rights Protection}

It is clear from this analysis how much human rights language has changed the consideration of austerity measures in English courts. It is clear that such change has come as a result of the indirect incorporation of the Convention and the adoption of domestic legislation-the Human Rights Act 1998 (HRA) as part of domestic protection of human rights. ${ }^{43}$ Yet, the possibility of the repeal of the HRA and the more generally negative attitude of the current political environment towards international agreements such as the Convention and the treaties of the European Union have raised concerns about the future of the protection of human rights in the UK. The current Prime Minister, Theresa May, has previously argued in favour of withdrawing from the Convention. The question therefore arises whether in the event of a UK exit of the Convention or the repeal of the HRA and other human rights legislation (such as the Equality Act) a sufficient legal basis could be found for the fulfilment of the international obligations. Can the UK achieve much the same protection of human rights as is enabled by the current legislation if it is no longer a member of the EU or the COE area?

Scholars have argued that in the recent case law of the English courts, including the Supreme Court, judges have sought to extend the protection of human rights not only through the application of legislation giving effect to the Convention, i.e. the HRA, but also and primarily by expanding the content of common law rights in English law. In three cases-Kennedy, ${ }^{44}$ Osborn $^{45}$ and Moohan ${ }^{46}$-English courts have recently asserted the precedence of the application of existing common law rights rather than having recourse to the HRA. They have criticised counsel for paying 'little attention to domestic administrative law' 47 and have effectively invited advocates to make such arguments before the Court in future cases; to rely on 'domestic' common law instead of norms stemming from an international source. In the words of Lord Toulson: '[t]he development of the common law did not come to an end on the passing of the Human Rights Act 1998. It is in vigorous health and flourishing in many parts of the world which share a common legal tradition, 48 Indeed, looking at the case law, the common law has incrementally developed and to a large extent reflects (though does not completely mirror) ${ }^{49}$ protections provided by the Convention. ${ }^{50}$

\footnotetext{
${ }^{43} \operatorname{Re}$ McKerr [2004] UKHL 12, [34] (Lord Nicholls), noting that the HRA creates 'domestic law rights corresponding to rights arising under the Convention'.

44 Kennedy v. Charity Commission [2014] UKSC 20.

45 Osborn v. Parole Board [2013] UKSC 61.

46 Moohan v. Lord Advocate [2014] UKSC 67.

47 Osborn (n. 2) [54] (Lord Reed).

${ }^{48} R$ (Guardian News and Media Ltd) v. City of Westminster Magistrates' Court [2012] EWCA Civ 420, [88] (Toulson LJ).

49 Elliott (2015).

${ }^{50} R$ (Daly) v. Secretary of State for the Home Department [2001] UKHL 26, [23] (Lord Bingham); Lord Bingham took a similar approach in A v. Secretary of State for the Home Department (No 2) [2005] UKHL 71, in which he noted that the conclusion was consistent with the protection accorded by Article 3 of the Convention.
} 
Affirming existing domestic law is important because it reveals that the common law remains alive in spite of the existence of the HRA. It rejects the position expressed by some judges, at the time of the entry into force of the HRA, which denied the need to further develop and expand the common law to ensure compliance with international obligations. Lord Rodger, for example, pointed out that "[i]n using the language of "constitutional rights", the judges were, more or less explicitly, looking for a means of incorporation avant la lettre, of having the common law supply the benefits of incorporation without incorporation'. ${ }^{1} \mathrm{He}$ insisted that '[n]ow that the [HRA] is in place, such heroic efforts are unnecessary'. ${ }^{52}$ By again recognising the relevance of common law and giving it priority, courts are able to frame their decision in domestic legal language and thus give the impression that human rights protection can be achieved without reference to international law.

Furthermore, the recent case law - as well as decisions pre-dating the HRA ${ }^{53}$ emphasises the ability of existing domestic norms to achieve compliance with the Convention (and thus the country's international obligations). Whilst international law may set out values to be protected and principles by which countries should abide, "[e]ven a cursory summary of international experience" ${ }^{54}$ indicates that international law is often too general and ambiguous to function as a problemsolving tool, pointing domestic courts to specific answers on how to accommodate and balance rights and public policy. ${ }^{55}$ For domestic courts such international law is 'only of limited assistance because it gives no more guidance than the text of the right itself'. ${ }^{56}$ International law is lacking both because it gives 'very little guidance with regard to the meaning to be given to each word' of, for example, an international agreement; ${ }^{57}$ because it fails to define the 'minimum core' of an international norm; ${ }^{58}$ and also because it contains 'no universally accepted bright lines for determining' how rights should be balanced. ${ }^{59}$ As Lord Reed in Osborn

\footnotetext{
51 Watkins v. Home Office [2006] UKHL 17, [64] (Lord Rodger).

52 Ibid.

53 See e.g. Leech (50).

54 Prinsloo v. Van der Linde 1997 (3) SA 1012, [18] (Ackermann, O’Regan and Sachs JJ).

55 Hovell and Williams (2005), pp. 95, 118. In this regard, international treaties are no different than domestic constitutions or other domestic human rights texts. Yet, whilst these domestic documents expect/authorise domestic courts to seek out answers to situations before them, international treaties only provide subsidiary jurisdiction to international courts and tribunals (if at all). As a consequence, the burden to seek out these international answers falls to domestic courts.
}

56 Ibid., p. 119. See also Khumalo v. Holomisa 2002 (5) SA 401, which concerned the freedom of expression in a defamation case. The South African Court did not refer to Article 19(2) of the ICCPR, which was relevant to the decision. Instead, it used comparative precedents from Australia, Canada, the UK and US.

57 S v. Williams 1995 (3) SA 632, [26] (Langa J), in which international sources were briefly enumerated but the focus was primarily directed towards foreign legal systems.

58 Government of the Republic of South Africa v. Grootboom 2001 (1) SA 46, [31]-[33]; Soobramoney v. Minister of Health 1998 (1) SA 765. The courts in both cases are criticised by Scott and Alston for not referring directly to the relevant international law (in Soobramoney) and for not exploring it fully (in Grootboom): Scott and Alston (2000), p. 206.

59 Prinsloo (n. 54) [18] (Ackermann, O’Regan and Sachs JJ). 
argued, at this high level of generality the guarantees set out in the international agreements 'have to be fulfilled at national level through a substantial body of much more specific domestic law'. ${ }^{6}$

In this context, the existing domestic norms and arrangements may be sufficient to comply with the Convention obligations and no further consideration of the ECtHR case law may be necessary. ${ }^{61}$ For example, as Lord Reed suggested in Osborn, the guarantee of a fair trial, under Article 6 of the Convention, is 'fulfilled primarily through detailed rules and principles to be found in several areas of domestic law, including the law of evidence and procedure, administrative law, and the law relating to legal aid' ${ }^{62}$ Similarly, the 'guarantee of a right to respect for private and family life, under Article 8, is fulfilled primarily through rules and principles found in such areas of domestic law as the law of tort, family law and constitutional law'. ${ }^{63}$ For example, in Daly, the House of Lords found that a policy that prisoners should be absent from their cells while they were being searched for contraband, as applied to a prisoner who had correspondence with his solicitor in his cell, was held to be unlawful on the ground that it infringed the prisoner's common law right that the confidentiality of privileged legal correspondence be maintained. The prohibition of admission of evidence obtained by torture, stipulated by the jurisprudence of Article 3 of the Convention, has been achieved by reference to English common law which had regarded torture and the evidence obtained by it with abhorrence for over 500 years. As Lord Bingham concluded in A v. Secretary of State for the Home Department (No 2), ${ }^{64}$ principles of the common law, standing alone, compelled the exclusion of third party torture evidence.

In all these cases, the domestic common law achieved precisely what was expected under the Convention. In Daly, the decision was compatible with Article 8 of the Convention; in A v. Secretary of State for the Home Department (No 2), the same result was achieved on the basis of the application of Article 3 of the Convention; and in Osborn, the approach adopted by the Court was consistent with, and supported by, that of the Strasbourg court.

Even more, it is not only rights mirroring those in the ECHR that have been recognised as forming part of the common law. ${ }^{65}$ The test of proportionality used both in EU and ECHR has now been recognised as part of the common law. In Pham, the Supreme Court adopted proportionality as a common law head of review and by doings so suggested that new fundamental and constitutional rights could arise or be recognised in common law. ${ }^{66}$ The key issue was whether it was lawful for the Home Secretary to strip the appellant of British citizenship whilst he still held Vietnamese citizenship. Although the decision was ultimately made on another ground, one of the arguments considered by the Court was whether depriving the

\footnotetext{
${ }^{60}$ Osborn (n. 2) [55] (Lord Reed).

61 Kennedy (n. 1) [46] (Lord Mance).

62 Osborn (n. 2) [55] (Lord Reed).

63 Ibid.

64 A v. Secretary of State for the Home Department (No 2) [2005] UKHL 71, [52] (Lord Bingham).

65 On the limits of internalisation see Fikfak (2015), p. 188.

66 Pham v. Secretary of State for the Home Department [2015] UKSC 19.
} 
claimant of his citizenship was disproportionate under European Union law. In their holding, the justices argued that proportionality was no longer linked only to EU and HRA context and indeed operated independently of these two areas, as a common law ground of review. In this context, beyond the simple means-fits-end analysis, proportionality was to be used as a vehicle for 'the scrutiny of justifications advanced for interferences with legal rights'. ${ }^{67}$ According to Lord Mance, depending on the importance of the right, 'a correspondingly strict standard of judicial review [...] the tool of proportionality is one which would [...] be both available and valuable for the purposes of such a review'. ${ }^{68}$ Or as Lord Reed said: 'Given the fundamental importance of citizenship, it may be arguable that the power to deprive a British citizen of that status should be interpreted as being subject to an implied requirement that its exercise should be justified as being necessary to achieve the legitimate aim pursued. ${ }^{69}$ Through statutory construction implied prohibitions would be read into the statute to prevent disproportionate interference with rights. ${ }^{70}$

If proportionality was to provide 'a flexible approach to principles of judicial review, particularly where important rights are at stake', ${ }^{71}$ then its recognition as a ground of review also suggests the emergence (or the potential for the recognition) of new common law rights. In Pham, the suggested higher intensity review which would attach to the deprivation of the individual of his 'fundamental' or 'constitutional' status as a British citizen, ${ }^{72}$ implicitly also suggests the (pre-)existence of a right. Government which wishes to deprive an individual of his citizenship, has to do so in a proportionate manner, ensuring that any interference with his right is 'no greater than is objectively established to be necessary to achieve the legitimate aim of the interference' ${ }^{73}$ In turn, a right 'not to be arbitrarily stripped of citizenship' emerges. ${ }^{74}$

The recent developments are encouraging from both a domestic and an international perspective. By relying on these existing domestic norms, norms that are separate and independent of the HRA, English judges have therefore taken the initiative to divorce the understanding of human rights protection as exclusively international in character and to strengthen the domestic, autonomous basis on which rights protection can be ensured in the UK. Courts have expanded concepts such as breach of confidence and developed them in compliance with the UK's international obligations. Their aim has been to 'afford appropriate protection to "privacy rights" under article 8 of the Convention'. ${ }^{75}$ In some areas, this transformation has been 'radical'. ${ }^{76}$ The action for breach of confidence, for

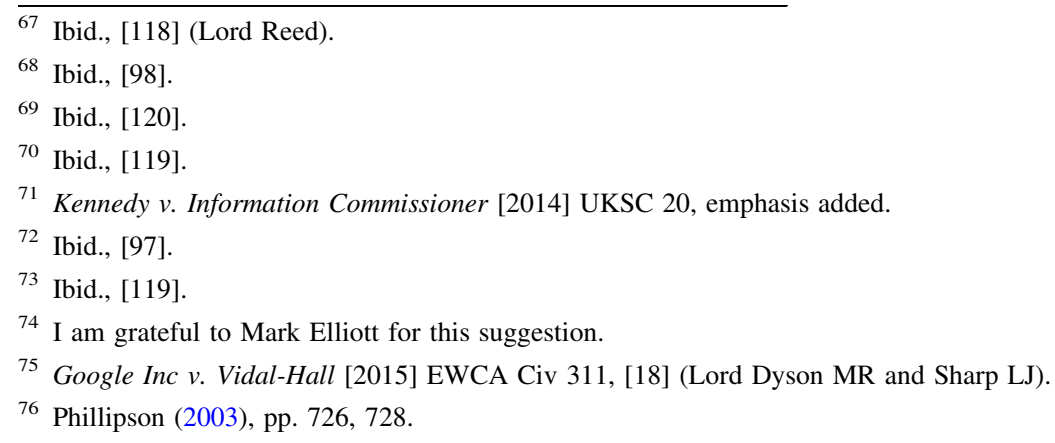


example, has been expanded so as to 'absorb[] the rights which articles 8 and 10 protect'. ${ }^{77}$ In fact, as Buxton LJ held in Ash v. McKennitt '[t]hose articles are now not merely of persuasive or parallel effect but [...] are the very content of the domestic tort that the English court has to enforce'. ${ }^{78}$ According to Google v. VidalHall, it is now clear that 'there are now two separate and distinct causes of action: an action for breach of confidence; and one for misuse of private information'. ${ }^{79}$ The incremental development of a domestic tort-breach of confidence-has through absorption of the rights and jurisprudence of the Convention led to a creation of a domestic privacy right. From case-to-case, the domestic norm took on a different, slightly bigger meaning, whilst all the while remaining the 'domestic' norm. The ultimate result therefore is that courts are today applying 'domestic' law, but there appears to be no question that its meaning and very content has been-at least on the basis of judicial statements - cross-fertilised by the Convention. ${ }^{80}$

If courts have and are still in the process of expanding the common law, then perhaps no legislative incorporation of the Convention is needed. Domestically, compliance with international norms can be ensured through the application of the common law. From an international perspective, in addition to the compliance it provides with international norms, the developments are important because the actions of the courts appear as an ideal example of internalisation of international norms into domestic law. Domestic courts appear to have adopted the internationally-friendly approach of reading domestic norms in accordance with international law and have done so voluntarily and of their own initiative. If in future common law rights can represent a basis for human rights protection, then this internalisation of international norms effectively bypasses the executive (and legislative) branch of government and reduces the political character assigned to international agreements by these political branches. Instead of treating international law as politics, courts will have asserted its legal nature. Finally, from the international perspective, the internalisation of international norms into domestic law through the common law enables international law to become part of the domestic value set and to redefine the state's national identity. In doing so, English courts may-although inadvertently-have accepted and become active participants in the international legal order by freeing themselves of the confines of the state and political branches and finally given international law the treatment it deserves as law.

Open Access This article is distributed under the terms of the Creative Commons Attribution 4.0 International License (http://creativecommons.org/licenses/by/4.0/), which permits unrestricted use, distribution, and reproduction in any medium, provided you give appropriate credit to the original author(s) and the source, provide a link to the Creative Commons license, and indicate if changes were made.

\footnotetext{
77 A v. B plc [2003] QB 195 [4] (Lord Woolf CJ).

78 Ash v. McKennitt [2006] EWCA Civ 1714, [11] (Buxton LJ); cited with approval in Lord Browne of Madingley v. Associated Newspapers Ltd [2008] QB 103, [21]-[22] (Clarke LJ).

79 Google Inc v. Vidal-Hall (n. 75) [22] (Lord Dyson MR and Sharp LJ).

${ }^{80}$ Clayton (2015), pp. 3, 7.
} 


\section{References}

Clayton R (2015) The empire strikes back: common law rights and the Human Rights Act. Public Law 3:7

Craig P (1999) The principle of proportionality in the law of Europe. OUP, pp 99-100

Elliott M (2015) A post-European British constitution: plus ça change. Curr Legal Probl 68:85-117

Elliott M, Beatson J, Matthews M (2014) Beatson, Matthews and Elliott's administrative law text and materials, 4th edn. OUP, p 267

Fikfak V (2015) English courts and the 'internalisation' of the European Convention of Human Rights?between theory and practice. UK Supreme Court Annu Rev Camb J Int Comp Law 5:188

Hovell D, Williams G (2005) Tale of two systems: the use of international law in constitutional interpretation in Australia and South Africa. Melb Univ Law Rev 29(95):118

Laws J (1998) Wednesbury. In: Forsyth C, Hare I (eds) The golden metwand and the crooked cord. Clarendon Press, Oxford, pp 185-187

Phillipson G (2003) Transforming breach of confidence-towards a common law right of privacy under the Human Rights Act. Mod Law Rev 66(726):728

Sales P, Steyn (2004) Legitimate expectations in English public law: an analysis. Public Law, p 546

Scott C, Alston P (2000) Adjudicating constitutional priorities in a transnational context: a comment on Soobramoney's legacy and Grootboom's promise. S Afr J Hum Rights 16:206 